\title{
Efficacy and safety of anakinra for the treatment of rheumatoid arthritis: an update of the Oregon Drug Effectiveness Review Project
}

This article was published in the following Dove Press journal:

Biologics:Targets \& Therapy

18 November 2009

Number of times this article has been viewed

\author{
Kylie Thaler' \\ Divya $V$ Chandiramani ${ }^{2}$ \\ Richard A Hansen ${ }^{2}$ \\ Gerald Gartlehner' \\ 'Department for Evidence-based \\ Medicine and Clinical Epidemiology, \\ Danube University Krems, Krems, \\ Austria; ${ }^{2}$ UNC Eshelman School \\ of Pharmacy, University of North \\ Carolina at Chapel Hill, Chapel Hill, \\ NC, USA
}

Objective: To systematically review the general and comparative efficacy and safety of anakinra for rheumatoid arthritis.

Methods: We searched MEDLINE ${ }^{\circledR}$, Embase, The Cochrane Library, and the International Pharmaceutical Abstracts from 1980 to April 2009. We manually searched reference lists of pertinent review articles and explored the Center for Drug Evaluation and Research database. For efficacy we included randomized controlled trials (RCTs) comparing anakinra with placebo or other biologics. For safety both experimental and observational studies were eligible. Two persons independently reviewed abstracts and full text articles and extracted relevant data.

Results: We included data from 3 RCTs comparing anakinra with placebo for rheumatoid arthritis (RA). The pooled relative risk (RR) of an ACR50 (American College of Rheumatology) response for anakinra compared with placebo is 2.28 (95\% CI 1.41 to 3.67). Adjusted indirect comparisons of ACR50 response rates of anakinra and anti-TNF agents showed a RR of 0.67 (95\% CI 0.38 to 1.17 ) favoring the anti-TNF drugs. This result did not reach statistical significance. For safety, we included 9 experimental and observational studies of 24 weeks to 3 years duration. Up to $30 \%$ of patients withdrew from the studies due to adverse events. $67.2 \%$ (95\% CI 38.7 to 95.7$)$ of patients experienced an injection site reaction.

Conclusions: Anakinra is an effective drug for treating RA. Indirect comparisons with adalimumab, etanercept and infliximab, however, showed a trend towards greater efficacy for the anti-TNF drugs. Anakinra also seems to be associated with comparably high rates of injection site reactions. These results should be taken into account when considering biologic therapy for patients with RA.

Keywords: anakinra, rheumatoid arthritis, infection

\section{Introduction}

Biologic agents have been approved for the treatment of rheumatic diseases, plaque psoriasis and inflammatory bowel diseases and have tremendously changed treatment strategies for these debilitating diseases. ${ }^{1}$ These agents include abatacept $\left(\right.$ Orencia $^{\circledR}$ ), adalimumab (Humira ${ }^{\circledR}$ ), alefacept $\left(\right.$ Amevive ${ }^{\circledR}$ ), anakinra $\left(\right.$ Kineret $\left.^{\circledR}\right)$, certolizumab pegol (Cimzia $\left.{ }^{\circledR}\right)$, etanercept $\left(\right.$ Enbrel $\left.^{\circledR}\right)$, golimumab (Simponi $\left.{ }^{\circledR}\right)$, infliximab (Remicade ${ }^{\circledR}$ ), natalizumab $\left(\right.$ Tysabri $\left.^{\circledR}\right)$, and rituximab (Rituxan $\left.{ }^{\circledR}\right)$. Evidence suggests that biologics are highly effective, although adverse events such as serious infections, lymphoma, leucopenia, malignancies, or demyelinations are of concern. ${ }^{2-9}$ Furthermore, they are considerably more expensive than standard treatment options. ${ }^{10,11}$ The cost of biologic drugs is expected to exceed US\$60 billion in
Correspondence: Kylie Thaler

Department for Evidence-based Medicine and Clinical Epidemiology, Danube University Krems, Dr-Karl-Dorrek-Str. 30, 3500 Krems, Austria

$\mathrm{Tel}+4327328932913$

Fax +4327328934910

Email kylie.thaler@donau-uni.ac.at 
the US by 2010 , representing a significant portion of the US drug industry. ${ }^{12}$

In general, biologic agents work by selectively blocking mechanisms involved in the inflammatory and immune response. For example, the biologics adalimumab, certolizumab pegol, etanercept, golimumab, and infliximab block tumor necrosis factor (TNF). ${ }^{13-15}$ In contrast, abatecept and alefacept interfere with T-lymphocyte activation. ${ }^{16}$ Natalizumab binds the alpha(4) integrin, which results in partial blockade of immune-cell adhesion to vascular endothelium and subsequent tissue migration of lymphocytes. ${ }^{17}$ Rituximab binds to the CD20 antigen on the surface of B lymphocytes, ${ }^{18}$ which are involved in autoimmune anti-inflammatory processes, such as those involved in rheumatoid arthritis (RA). Finally, anakinra is a recombinant IL-1 (interleukin-1) receptor antagonist and has the same properties as the human IL-1 receptor agonist. Anakinra binds to the IL-1 receptor and inhibits pro-inflammatory effects by blocking signal transduction. ${ }^{4-6,19}$

Dosing regimens and route of administration vary considerably among the various agents. Abatacept, infliximab, and rituximab are administered intravenously; adalimumab, anakinra and etanercept are administered subcutaneously. Abatacept is infused in doses of 500 to $1000 \mathrm{mg}$ repeated at 2 and 4 weeks and every 4 weeks thereafter. Infliximab infusions are administered in doses of $3 \mathrm{mg} / \mathrm{kg}$ at 0,2 , and 6 weeks followed by maintenance every 8 weeks and rituximab is dosed at $1000 \mathrm{mg}$ on days 1 and 15 . Adalimumab is injected subcutaneously at $40 \mathrm{mg}$ every other week, and etanercept is administered at $50 \mathrm{mg}$ per week. ${ }^{11}$ In comparison, anakinra is administered in doses of $100 \mathrm{mg}$ subcutaneously every day. The burden of daily subcutaneous administration of anakinra might disadvantage it compared with the other biologic agents. Table 1 presents a summary of dosing and administration of the biologics.

Considering the high cost and differing regimes of the biologics, it is important to ascertain their comparative effectiveness. This systematic review and meta-analysis is a result of work conducted for the Oregon Drug Effectiveness Review Project (DERP) on the comparative efficacy and safety of 10 specific biologics for rheumatoid arthritis (RA), ankylosing spondylitis, psoriatic arthritis, Crohn's disease, ulcerative colitis, plaque psoriasis, and juvenile idiopathic arthritis in adult out-patients and subgroups including children. In a meta-analysis of studies up to January 2005 indirect comparisons suggested that anakinra is inferior to the anti-TNF biologics for RA. ${ }^{20}$ In this report we focus on the general and comparative benefits and risks of anakinra and provide an update of this result with several newer studies included in the analysis.

\section{Methods}

\section{Data sources}

We searched MEDLINE ${ }^{\circledR}$, Embase, Cochrane Library, and International Pharmaceutical Abstracts from 1980 up to April 2009. We used either Medical Subject Headings $(\mathrm{MeSH})$ as search terms when available or key words when appropriate. In the original DERP report, ${ }^{11}$ we combined terms for RA, ankylosing spondylitis, psoriatic arthritis, Crohn's disease, ulcerative colitis, plaque psoriasis, and juvenile idiopathic arthritis with a list of ten specific biologics-abatacept (Orencia ${ }^{\circledR}$ ), adalimumab $\left(\right.$ Humira $^{\circledR}$ ), alefacept (Amevive ${ }^{\circledR}$ ), anakinra (Kineret ${ }^{\circledR}$ ), certolizumab $\left(\text { Cimzia }^{\circledR}\right)^{*}$, etanercept $\left(\right.$ Enbrel $\left.^{\circledR}\right)$, infliximab $\left(\right.$ Remicade $^{\circledR}$ ), natalizumab $\left(\right.$ Tysabri $\left.^{\circledR}\right)$, rituximab (Rituxan ${ }^{\circledR}$ ). For this review we limited results to literature identified for anakinra. For the other biologics, we present comparisons with anakinra only. We did not review data on golimumab because it was not on the market at the time of this review, and excluded efalizumamab because it was voluntarily withdrawn from the market. We limited electronic searches to "human" and "English language."

We manually searched reference lists of pertinent review articles and letters to the editor and used the Center for Drug Evaluation and Research database to identify unpublished research submitted to the FFDA. The Scientific Resource Center of the Oregon Health and Science University invited pharmaceutical manufacturers to submit dossiers on completed research for each drug.

\section{Study selection}

Two persons independently reviewed abstracts and relevant full-text articles. To assess efficacy or effectiveness for response and quality of life we included randomized controlled trials (RCTs) and prospective controlled observational studies of at least 12 weeks duration that compared anakinra with placebo or another biologic. To assess harms (specific adverse events, rates of adverse events, and discontinuations attributable to adverse events), we also examined data from retrospective observational studies with $\geq 100$ participants and follow-up of at least 6 months. Table 2 summarizes the eligibility criteria.

If both reviewers agreed that the study did not meet eligibility criteria, we excluded it. We also excluded studies that met eligibility criteria but were reported only 
Table I Administration and dosing

\begin{tabular}{|c|c|c|c|}
\hline Drug & Mechanism & Route & Dose \\
\hline Abatacept & CTLA 4-Ig & IV & $\begin{array}{l}\text { Adult: dosed according to body weight }(<60 \mathrm{~kg}=500 \mathrm{mg} ; 60-100 \mathrm{~kg}=750 \mathrm{mg} \text {; } \\
>100 \mathrm{~kg}=1000 \mathrm{mg} \text { ); dose repeated at } 2 \text { weeks and } 4 \text { weeks after initial dose, and } \\
\text { every } 4 \text { weeks thereafter } \\
\text { Pediatric: for children } \geq 6 \text { years and }<75 \mathrm{~kg} \text { dose is } 10 \mathrm{mg} / \mathrm{kg} \text {, repeat dose at } 2 \text { and } \\
4 \text { weeks after initial infusion, and every } 4 \text { weeks thereafter. For children } \geq 6 \text { years } \\
\text { and }>75 \mathrm{~kg} \text { the dose is } 750 \mathrm{mg} \text { if child is } 75-100 \mathrm{~kg} \text {; dose is } 1000 \mathrm{mg} \text { if child }>100 \mathrm{~kg}\end{array}$ \\
\hline Adalimumab & TNF inhibitor & SQ & $\begin{array}{l}\text { RA: } 40 \mathrm{mg} \text { every other week; patients not taking methotrexate may increase to } \\
40 \mathrm{mg} \text { per week for adalimumab monotherapy } \\
\text { PsA, AS: } 40 \mathrm{mg} \text { every other week } \\
\text { Plaque psoriasis: initial } 80 \mathrm{mg} \text { as a single dose; maintenance dose is } 40 \mathrm{mg} \text { every other } \\
\text { week beginning I week after initial dose } \\
\text { Crohn's disease: initial dose of } 160 \mathrm{mg} \text { given as } 4 \text { injections on day I or over } 2 \text { days, } \\
\text { then } 80 \mathrm{mg} 2 \text { weeks later (day I5); Maintenance dose is } 40 \mathrm{mg} \text { every other week begin- } \\
\text { ning day } 29 \\
\text { Pediatric: } 15 \mathrm{~kg} \text { to }<30 \mathrm{~kg}: 20 \mathrm{mg} \text { every other week; } \geq 30 \mathrm{~kg}: 40 \mathrm{mg} \text { every other week }\end{array}$ \\
\hline Alefacept & CD2 antagonist & IM & $\begin{array}{l}\text { I } 5 \text { mg given once weekly, treatment should be continued for } 12 \text { weeks; re-treatment } \\
\text { with an additional I } 2 \text { week course may be initiated provided that CD } 4+T \text { lymphocytes } \\
\text { counts are }>250 \text { cells } / \mu \mathrm{L} \text { and a I } 2 \text {-week interval has passed since the end of the initial } \\
\text { treatment cycle }\end{array}$ \\
\hline Anakinra & $\begin{array}{l}\text { IL-I receptor } \\
\text { antagonist }\end{array}$ & SQ & $\begin{array}{l}\text { RA: I } 00 \mathrm{mg} \text { once daily; dose maybe decreased to } 100 \mathrm{mg} \text { every other day in cases of } \\
\text { renal impairment }\end{array}$ \\
\hline $\begin{array}{l}\text { Certolizumab } \\
\text { pegol }\end{array}$ & TNF inhibitor & SQ & $\begin{array}{l}\text { RA: Initial dose is } 400 \mathrm{mg} \text {, repeat dose } 2 \text { and } 4 \text { weeks after initial dose. Maintenance } \\
\text { dose is } 200 \mathrm{mg} \text { every other week. May consider maintenance dose of } 400 \mathrm{mg} \text { every } \\
4 \text { weeks } \\
\text { Crohn's disease: Initial dose is } 400 \mathrm{mg} \text {, repeat dose } 2 \text { and } 4 \text { weeks after initial dose. } \\
\text { Maintenance dose is } 400 \mathrm{mg} \text { every other week }\end{array}$ \\
\hline Etanercept & TNF inhibitor & SQ & $\begin{array}{l}\text { RA, PsA, AS: } 25 \mathrm{mg} \text { twice weekly or } 50 \text { once weekly } \\
\text { Plaque psoriasis: Initial dose of } 50 \mathrm{mg} \text { twice weekly, } 3-4 \text { days apart, maintain initial dose } \\
\text { for } 3 \text { months, } \\
\text { Maintenance dose is } 50 \mathrm{mg} \text { once weekly } \\
\text { Pediatric: } 0.8 \mathrm{mg} \text { once weekly or } 0.4 \mathrm{mg} \text { twice weekly (maximum of } 50 \mathrm{mg} \text { ) }\end{array}$ \\
\hline Golimumab & TNF inhibitor & SQ & RA, PsA, AS: 50 mg once per month \\
\hline Infliximab & TNF inhibitor & IV & $\begin{array}{l}\text { RA: } 3 \mathrm{mg} / \mathrm{kg} \text { at } 0,2 \text {, and } 6 \text { weeks followed by maintenance every } 8 \text { weeks thereafter; } \\
\text { may increase to maximum of } 10 \mathrm{mg} / \mathrm{kg} \text { every } 4 \text { weeks } \\
\text { AS: } 5 \mathrm{mg} / \mathrm{kg} \text { at } 0,2 \text {, and } 6 \text { weeks, followed by } 5 \mathrm{mg} / \mathrm{kg} \text { every } 6 \text { weeks thereafter } \\
\text { Plaque psoriasis: } 5 \mathrm{mg} / \mathrm{kg} \text { at } 0,2 \text {, and } 6 \text { weeks, then every } 8 \text { weeks thereafter } \\
\text { Ulcerative colitis: } 5 \mathrm{mg} / \mathrm{kg} \text { at } 0,2 \text {, and } 6 \text { weeks, followed by } 5 \mathrm{mg} / \mathrm{kg} \text { every } 8 \text { weeks } \\
\text { thereafter } \\
\text { Pediatric Crohn's disease: } 5 \mathrm{mg} / \mathrm{kg} \text { at } 0,2 \text {, and } 6 \text { weeks, followed by a maintenance dose } \\
\text { of } 5 \mathrm{mg} / \mathrm{kg} \text { every } 8 \text { weeks; if no response by week } 14 \text {, consider discontinuing therapy }\end{array}$ \\
\hline Natalizumab & $\begin{array}{l}\text { Alpha } 4 \text { integrin } \\
\text { blocker }\end{array}$ & IV & Crohn's disease: 300 mg infused over I hour every 4 weeks \\
\hline Rituximab & Anti-CD 20a & IV & RA: $1000 \mathrm{mg}$ on days I and I5 in combination with methotrexate \\
\hline
\end{tabular}

Abbreviations: AS, ankylosing spondylitis; CTLA 4-Ig, cytotoxic T-lymphocyte antigen 4; TNF, tumor necrosis factor; IL-I, interleukin-I; CD, cluster of differentiation; IM, intramuscular; IV, intravenous; PsA, psoriatic arthritis; RA, rheumatoid arthritis; SQ, subcutaneous.

as an abstract. Investigators resolved disagreements about inclusion or exclusion by consensus or by involving a third reviewer.

\section{Data extraction and quality assessment}

We used a structured data abstraction form into which trained reviewers abstracted data from each study and assigned an initial quality rating. Abstracted data included the baseline characteristics of the included patients, health-related outcomes (such as quality of life, response, remission, pain, hospitalization and mortality), adverse events, and overall and differential attrition. A senior reviewer read each abstracted article, evaluated completeness of data abstraction, and confirmed the quality rating. Investigators resolved any disagreements by discussion and consensus or by consulting an independent party. 
Table 2 Eligibility criteria

\begin{tabular}{|c|c|}
\hline Population & Adult outpatients with rheumatoid arthritis \\
\hline Intervention & $\begin{array}{l}\text { Anakinra alone or in combination with other } \\
\text { DMARDs or biologics }\end{array}$ \\
\hline Comparison & Placebo or other biologic \\
\hline Outcomes & $\begin{array}{l}\text { Health-related outcomes (eg: quality of } \\
\text { life, response) Harms (adverse events, } \\
\text { discontinuation due to adverse events) }\end{array}$ \\
\hline $\begin{array}{l}\text { Study design and } \\
\text { timing (efficacy) }\end{array}$ & $\begin{array}{l}\text { Controlled trial, } \geq 12 \text { weeks study duration, } \\
N \geq 30\end{array}$ \\
\hline $\begin{array}{l}\text { Study design and } \\
\text { timing (safety) }\end{array}$ & $\begin{array}{l}\text { Observational study, }>6 \text { months, } \geq 100 \\
\text { participants }\end{array}$ \\
\hline
\end{tabular}

Abbreviation: DMARD, disease-modifying antirheumatic drug.

We assessed the internal validity (quality) of trials based on predefined criteria and applied ratings of good, fair, or poor. ${ }^{21}$ Primary elements of quality assessment for RCTs included randomization and allocation concealment, similarity of compared groups at baseline, blinding, use of intention-to-treat analysis, and overall and differential loss to follow-up. To assess observational studies we used criteria involving selection of cases or cohorts and controls, adjustment for confounders, methods of outcomes assessment, length of follow-up, and statistical analysis. ${ }^{22}$ Studies with a fatal flaw in one or more categories were rated "poor" quality.

To identify effectiveness studies, we used a tool that distinguishes efficacy trials from effectiveness studies based on certain elements of study design. ${ }^{23}$ Such studies have a higher applicability of results than efficacy trials because they enroll less selected study populations, employ treatment modalities that mimic clinical practice, and assess health outcomes along with adverse events.

\section{Data synthesis}

Where data were insufficient to conduct meta-analyses (ie, too sparse or too heterogeneous), we synthesized the evidence on the majority of outcomes qualitatively. Where data from RCTs were sufficient, we conducted meta-analyses. The outcome of interest for efficacy was the number of patients achieving a response according to the ACR scoring system (American College of Rheumatology). We chose ACR50 as the primary outcome measure because a 50\% improvement is likely to translate to a clinically significant improvement in health-related quality of life. For example, a patient with 12 swollen and 8 tender joints at baseline would need to have fewer than 6 swollen and 4 tender joints at the trial endpoint. This would be accompanied by at least a $50 \%$ improvement in at least 3 of the following 5 measures: the patient's assessment of pain, the patient's assessment of global disease activity, the physician's assessment of global disease activity, the Health Assessment Questionnaire (HAQ)-Disability Index, and either a C-reactive protein (CRP) or sedimentation rate (Westergren erythrocyte sedimentation rate [WESR]). In addition, we report the results for an ACR20 (20\% improvement) and ACR70 (70\% improvement).

For each meta-analysis, we conducted a test of heterogeneity ( $\mathrm{I}^{2}$ index) and applied both random and fixed effects models. We consider $\mathrm{I}^{2}$ greater than $60 \%$ to be too high to compare data. We report the random effects results because the results from both models were very similar in all metaanalyses. We assessed publication bias using funnel plots and Kendell's tests. All statistical analyses used StatsDirect Statistical Software program, version 2.6.6 (StatsDirect LTD, 2008).

Because only limited head-to-head evidence on biologics was available, we conducted adjusted indirect comparisons when data was sufficient and trials were of similar design, conducted in similar settings with a comparable patient population. However, because of limited data on individual biologics as active comparators, we assessed the comparative risk of anakinra relative to anti-TNF agents as a class. We based these analyses on the method proposed by Bucher et al. ${ }^{24}$ Evidence suggests that adjusted indirect comparisons agree with head-to-head trials if component studies are similar and treatment effects are expected to be consistent in patients included in different trials. ${ }^{25,26}$ Nevertheless, findings must be interpreted cautiously.

\section{Results}

In the original DERP report on biologics, we identified 3451 citations from searches and reviews of reference lists. Of these, 236 articles met the inclusion criteria and were included. Some studies had multiple publications. Finally, for this report on anakinra, we included 4 RCTs for efficacy and 5 additional studies for saftey. Figure 1 represents the results of the literature search and the disposition of the literature. We did not find any study that could be classified as an effectiveness trial. All trials reported on anakinra for the treatment of rheumatoid arthritis. We did not locate any publication that met our inclusion criteria for psoriatic arthritis, plaque psoriasis, ankylosing spondylitis, juvenile idiopathic arthritis, Crohn's disease or ulcerative colitis (all other indications covered in the DERP report). 


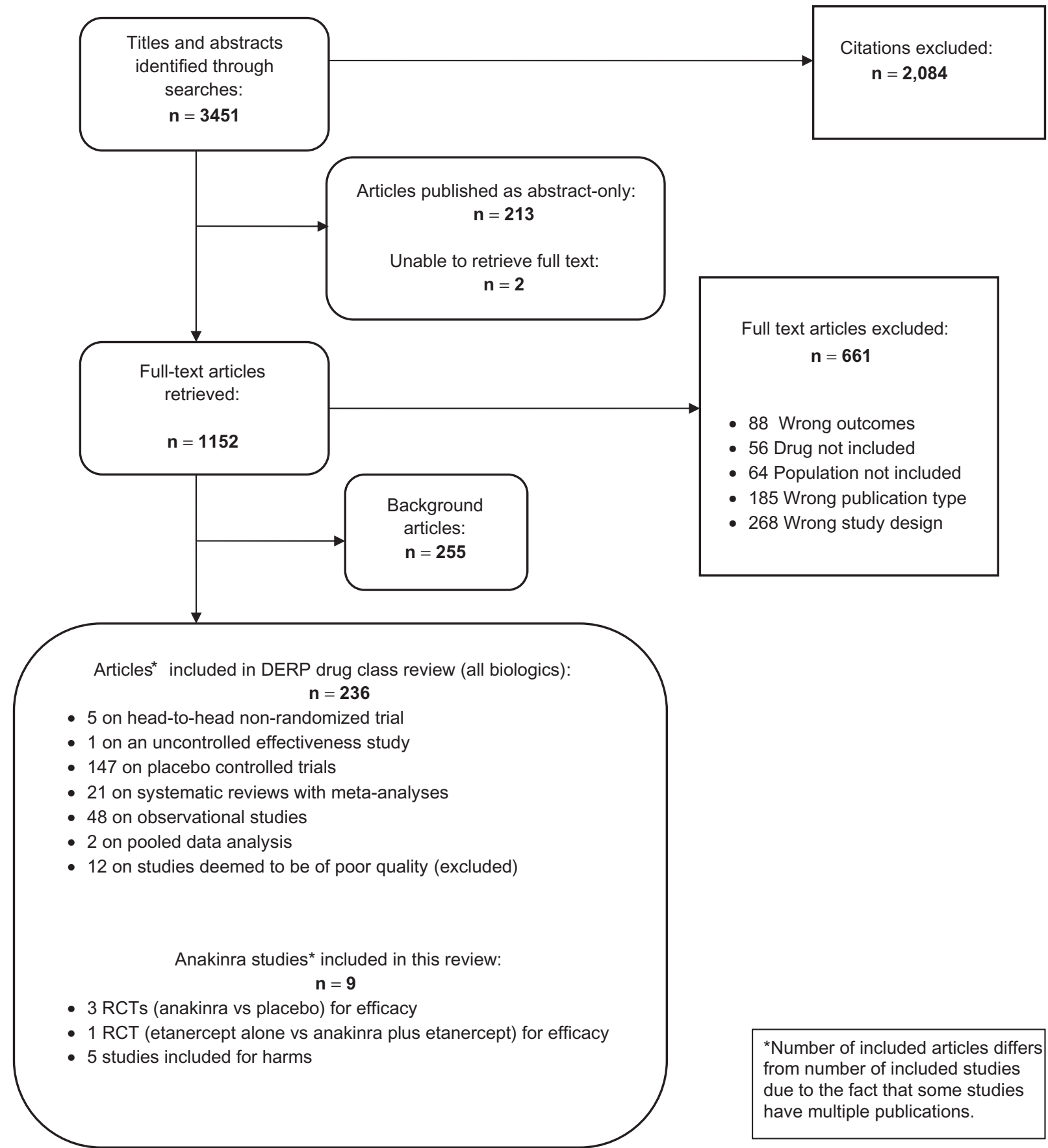

Figure I Disposition of the literature.

Abbreviation: DERP, oregon drug effectiveness review project.

\section{Efficacy of anakinra}

We located 5 publications that met our inclusion criteria for efficacy in patients with rheumatoid arthritis. Three RCTs reported on the efficacy of anakinra compared with placebo, ${ }^{27-29}$ and 1 RCT compared anakinra in combination with etanacerpt with etanacerpt alone. ${ }^{30} \mathrm{We}$ found additional information on ACR response rates for $1 \mathrm{RCT}^{27}$ in the CDER database..$^{31}$ One RCT was published as an abstract only ${ }^{32}$ Table 3 presents a summary of the included studies.

\section{Population and outcome measures}

A total of 1625 patients were included in the trials. All patients suffered from active RA of at least 3 to 6 months duration. Mean disease duration varied between 6 and 10 years. Trials variably allowed concomitant treatment with a stable dose of 
Table 3 Summary of anakinra (AKA) efficacy studies

\begin{tabular}{|c|c|c|c|c|c|c|}
\hline Author & $\begin{array}{l}\text { Study } \\
\text { design, } \\
\mathbf{N} \text {, duration }\end{array}$ & Comparisons & Outcomes & Population & Results & $\begin{array}{l}\text { Quality } \\
\text { rating }\end{array}$ \\
\hline \multicolumn{7}{|c|}{ Anakinra compared with placebo } \\
\hline $\begin{array}{l}\text { Bresnihan } \\
\text { et } \mathrm{al}^{27}\end{array}$ & $\begin{array}{l}\text { RCT } \\
472 \\
24 \text { wks }\end{array}$ & $\begin{array}{l}\text { AKA (30 mg, } 70 \text { mg, } \\
\text { I } 50 \text { mg/day) vs placebo }\end{array}$ & $\begin{array}{l}\text { ACR20, Paulus crit., } \\
\text { SJC,TJC, HAQ, } \\
\text { Larsen score, pain } \\
\text { (VAS), morning } \\
\text { stiffness }\end{array}$ & $\begin{array}{l}>6 \text { months active } \\
\text { severe RA, NSAIDs, } \\
\text { steroids }<10 \mathrm{mg} / \text { day } \\
\text { allowed, no other } \\
\text { DMARDs }\end{array}$ & $\begin{array}{l}\text { Significant improvement } \\
\text { in all ACR components } \\
\text { (SJC,TJC, disease activity, } \\
\text { pain ESR) in I } 50 \text { mg/day } \\
\text { group compared with } \\
\text { placebo group }\end{array}$ & Fair \\
\hline $\begin{array}{l}\text { Cohen } \\
\text { et } \mathrm{a}^{28}\end{array}$ & $\begin{array}{l}\text { RCT } \\
419 \\
24 \text { wks }\end{array}$ & $\begin{array}{l}\text { AKA }(0.04,0.1,0.4 \text {, } \\
\text { I.0, } 2.0 \mathrm{mg} / \mathrm{kg} / \text { day }) \text { vs } \\
\text { placebo }\end{array}$ & $\begin{array}{l}\text { ACR20, } \\
\text { ACR50/70, HAQ, } \\
\text { morning stiffness }\end{array}$ & $\begin{array}{l}\text { 6- to 8-year history } \\
\text { of moderate-severe } \\
\text { RA, stable dose MTX } \\
\text { (I5-25 mg/week) }\end{array}$ & $\begin{array}{l}\text { More patients in AKA } \\
\text { I mg/kg had ACR20 } \\
\text { response ( } 42 \%) \text { than } \\
\text { placebo group ( } 23 \%) \text {. } \\
\text { More patients in } \\
\text { AKA I mg/kg and } \\
2 \mathrm{mg} / \mathrm{kg} \text { groups had an } \\
\text { improvement on HAQ } \\
\text { and pain }\end{array}$ & Fair \\
\hline $\begin{array}{l}\text { Cohen } \\
\text { et } \mathrm{al}^{30}\end{array}$ & $\begin{array}{l}\text { RCT } \\
501 \\
24 \text { wks }\end{array}$ & $\begin{array}{l}\text { AKA }(100 \mathrm{mg} / \text { day }) \text { vs } \\
\text { placebo }\end{array}$ & $\begin{array}{l}\text { ACR } 20, \\
\text { ACR } 50 / 70, \mathrm{HAQ}, \\
\text { TJC, SJC }\end{array}$ & $\begin{array}{l}\text { >6-month history of } \\
\text { active RA; stable } \\
\text { MTX regimen } \\
\text { 10-25 mg/wk; mean } \\
\text { disease duration: } \\
10.5 \text { years }\end{array}$ & $\begin{array}{l}\text { Significantly more } \\
\text { patients in AKA group } \\
\text { achieved a response } \\
\text { (ACR20/50/70). } \\
\text { Decrease in TJC greater } \\
\text { in the AKA group }\end{array}$ & Fair \\
\hline \multicolumn{7}{|c|}{ Anakinra in combination with another biologic } \\
\hline $\begin{array}{l}\text { Genovese } \\
\text { et } \mathrm{al}^{30}\end{array}$ & $\begin{array}{l}\text { RCT } \\
242 \\
24 \text { wks }\end{array}$ & $\begin{array}{l}\text { ETA ( } 25 \mathrm{mg} / \text { week or } \\
50 \mathrm{mg} / \text { week) plus } \\
\text { AKA (100 mg/day) vs } \\
\text { ETA alone }\end{array}$ & $\begin{array}{l}\text { ACR50, } \\
\text { ACR20/70, EULAR, } \\
\text { DAS, SF-36 }\end{array}$ & $\begin{array}{l}>6 \text {-month history } \\
\text { of RA; }>16 \text { weeks } \\
\text { MTX and }>8 \text { weeks } \\
\text { stable dose MTX of } \\
\text { 10-25 mg/week; } 50 \% \\
\text { also using steroids }\end{array}$ & $\begin{array}{l}\text { Overall, no significant } \\
\text { difference in efficacy } \\
\text { between treatment } \\
\text { groups }\end{array}$ & Fair \\
\hline
\end{tabular}

Abbreviations: ACR20/50/70, American College of Rheumatology (numbers refer to percentage improvement); AKA, anakinra; ASHI, arthritis-specific health index; DAS28, disease activity score; DMARD, disease-modifying antirheumatic drug; ETA, etanercept; EULAR, European League Against Rheumatism; HAQ, Health Assessment Questionnaire; Larsen score, radiographic evaluation; MA, meta-analysis; MTX, methotrexate; RA, rheumatoid arthritis; RCT, randomized controlled trial; SF-36, Medical Outcomes Study Short Form 36 Health Survey; SJC, swollen joint count; TJC, tender joint count; VAS, visual analogue score.

MTX and/or corticosteroids. Most patients used NSAIDS in addition to the study medication. The majority of patients in the trials had active disease despite therapy with at least one disease-modifying anti-rheumatic drug (DMARD). Patients with an autoimmune disease other than RA, a history of active listeriosis or mycobacterial infection, another infection or recent antibiotic treatment were generally excluded from studies. Between $70 \%$ and $80 \%$ of trial participants were female.

All trials assessed response rates after 24 weeks of therapy as defined by the ACR. One trial also reported the European League Against Rheumatism (EULAR) response rate. ${ }^{30}$ In addition, three studies evaluated functional capacity with the HAQ. ${ }^{27-29}$

All studies were funded by Amgen Inc., Thousand Oaks, California. ${ }^{28-30}$

\section{Anakinra compared with placebo}

Three fair RCTs compared various doses of anakinra with placebo (between $0.04 \mathrm{mg} / \mathrm{kg} /$ day and $150 \mathrm{mg}$ /day) for patients with moderate to severe RA that had not responded to DMARDs. ${ }^{27-29}$ Two studies allowed concomitant treatment with MTX. ${ }^{28,29}$ All three studies lasted 24 weeks. In total, 1392 patients were randomized to anakinra $(\mathrm{N}=946)$ or placebo $(\mathrm{N}=446)$. Based on the ACR criteria, significantly more patients receiving anakinra $100 \mathrm{mg} /$ day, $150 \mathrm{mg} /$ day, $1 \mathrm{mg} / \mathrm{kg} / \mathrm{day}$, or $2 \mathrm{mg} / \mathrm{kg} / \mathrm{day}$ responded to treatment compared with placebo. Specifically, the pooled relative risk of an ACR50 response for the approved doses of anakinra compared with placebo is 2.28 ( $95 \%$ CI 1.41 to 3.67). The RR for an ACR20 response is 1.73 (95\% CI 1.34 to 2.25) and for an ACR70 response 2.90 (95\% CI 1.21 to 6.97) (see Figure 2). 
A ACR20 Relative risk meta-analysis plot (random effects)

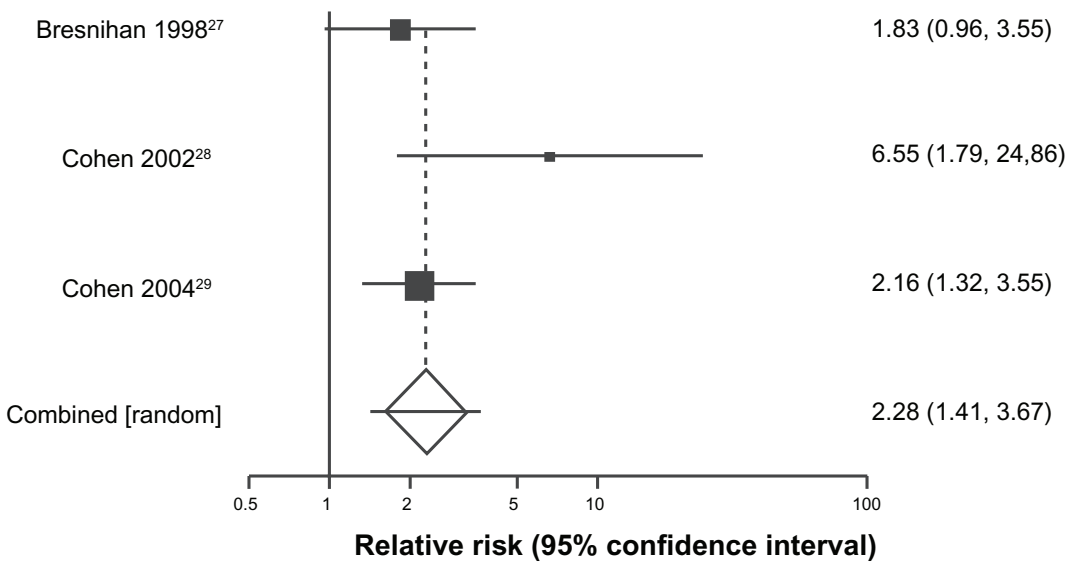

B ACR50 Relative risk meta-analysis plot (random effects)

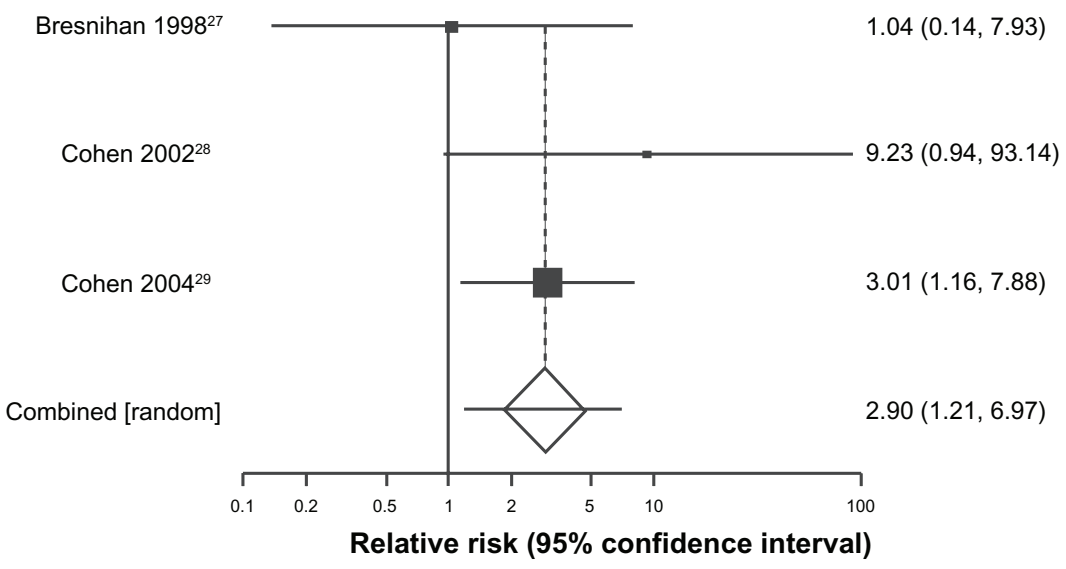

C ACR70 Relative risk meta-analysis plot (random effects)

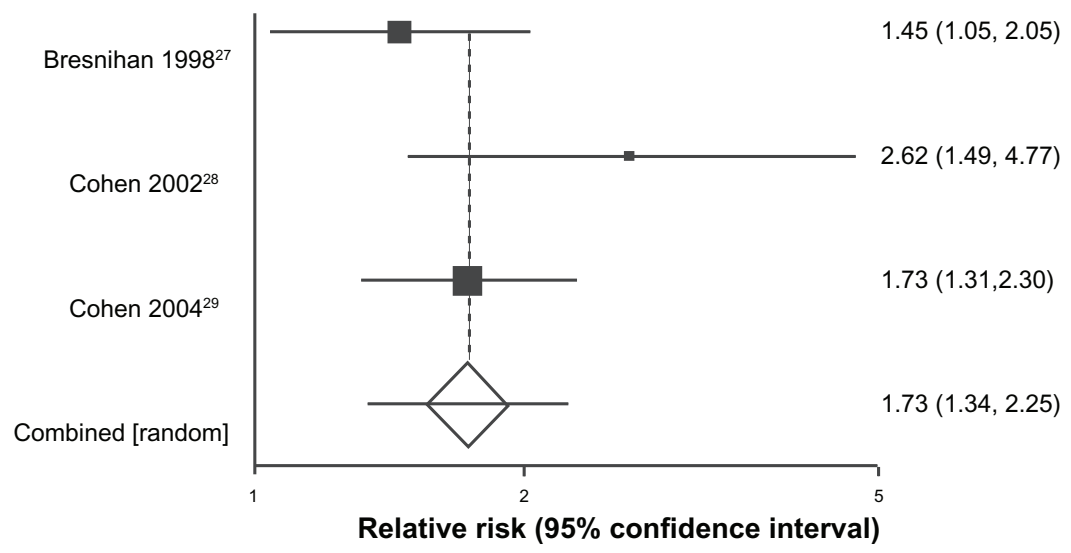

Figure 2 Meta-analysis of ACR20,ACR50 and ACR70 response (anakinra vs placebo). 
In addition, in all three RCTs, patients receiving anakinra demonstrated a greater improvement in health assessment questionnaire (HAQ) than patients receiving placebo score (approximately 0.4 for anakinra compared to 0.2 for placebo; scale values 0 to 3 ). This result reached statistical significance for all doses except one ( $2 \mathrm{mg} / \mathrm{kg} /$ day $)$.

\section{Comparative efficacy}

We did not locate any trials that directly compared anakinra to another biologic. Because of the lack of direct head-to-head evidence for anakinra compared with other biologics we conducted adjusted indirect comparisons based on meta-analyses of placebo-controlled trials to compare the treatment effects of individual biologics. We included data from published studies or from the CDER website. For all analyses we used only data derived from study arms at or near the recommended dosage. We did not perform indirect comparisons for biologics other than adalimumab, etanercept, and infliximab because the populations included in the trials were too heterogenous compared with the anakinra trials and therefore performing indirect comparisons may lead to erroneous conclusions. Appendix 1 summarizes studies included for indirect comparisons.

For ACR50 response, point estimates of anakinra compared with the anti-TNF biologics consistently favored the comparator: adalimumab (RR $0.64,95 \%$ CI 0.36 to 1.14 ); etanercept (RR $0.41,95 \%$ CI 0.13 to 1.31 ); and infliximab (RR $0.69,95 \%$ CI 0.41 to 1.18 ). Compared with anti-TNF agents as a class, the RR of an ACR50 response is 0.67 (95\% CI 0.38 to 1.17$)$. That differences do not reach statistical significance is likely attributable to a lack of power. Despite this, the differences may be clinically relevant.

Figure 3 depicts results of adjusted indirect comparisons of anakinra with adalimumab, etanercept, infliximab, and anti-TNF drugs as a class. The evidence on abatacept, certolizumab, and rituximab was insufficient or too heterogeneous to be included for indirect comparisons.

\section{General efficacy of anakinra for other indications}

We did not locate any published studies of anakinra for psoriatic arthritis, plaque psoriasis, ankylosing spondylitis, juvenile idiopathic arthritis, Crohn's disease, or ulcerative colitis.

\section{Safety of anakinra}

\section{General safety}

For safety we included the three RCTs included for efficacy, ${ }^{27-29} 1$ RCT of anakinra plus etanercept compared with etaercerpt alone, ${ }^{30}$ and one 6-month RCT of anakinra versus placebo with a 3-year open treatment follow-up phase. ${ }^{4-6,33}$

In addition, we located 1 RCT that reported the safety results of 3 doses of anakinra. ${ }^{19}$ (This study is an extension of Bresnihan et al. Patients who had received placebo in the initial 24 weeks were re-randomized to $30 \mathrm{mg} /$ day, $75 \mathrm{mg} /$ day, or $150 \mathrm{mg}$ /day of anakinra and followed up for an additional 52 weeks). We also included safety data comparing patients taking anakinra and conventional DMARDs from

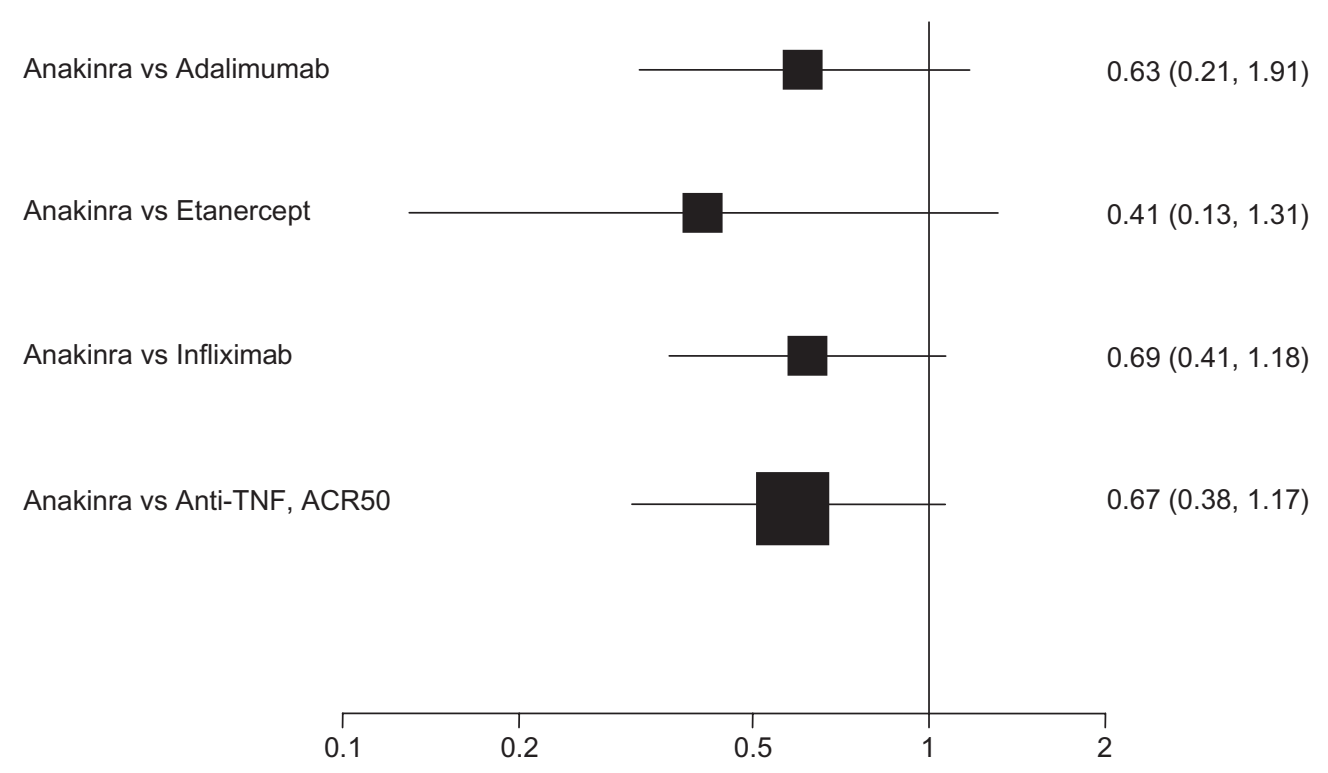

Figure 3 Adjusted indirect comparisons of anakinra with anti-TNF drugs for an ACR50 response. Abbreviation: RR, relative risk. 
the German RABBIT Registrar (RABBIT = Rheumatoid Arthritis - Observation of Biologic Therapy) $)^{34,35}$ and a case series of patients receiving anakinra. ${ }^{36}$ Table 4 presents a summary of the studies included for safety.

Overall, between $6.5 \%$ and $30 \%$ of patients withdrew from anakinra therapy due to adverse events compared with $4 \%$ to $13 \%$ of patients on placebo. The most common adverse event was injection site reaction. The mean, crude incidence of injection site reactions was $67.2 \%(95 \%$ CI 38.7 to 95.7$).{ }^{11}$

Infections occurred in $5 \%$ to $33 \%$ of patients taking anakinra compared with $12 \%$ to $26 \%$ of placebo-treated patients. Infections included influenza-like symptoms, respiratory infections, and urinary tract infections. We located 1 systematic review that reported on the safety of anakinra. ${ }^{37}$ The authors included all 4 RCTs of anakinra versus placebo for rheumatoid arthritis that we also located. ${ }^{6,27-29}$ Thirty serious infections $(1.4 \%)$ occurred in the anakinra groups compared with 4 in the placebo groups $(0.5 \%)$. The metaanalysis of the studies demonstrated an odds ratio for serious infections of 2.75 (95\% CI 0.91 to 8.35$).{ }^{37}$

Two of the 24-week RCTs reported 2 malignancies each that were "not considered to be related to the study medication", ${ }^{27,28}$ The 3-year open label study of anakinra ${ }^{33}$ reported a higher than expected incidence of melanoma and lymphoma (incidence compared with data from the general population). The results submitted to the CDER by Amgen reported that " 21 malignancies of various types were observed in 2531 rheumatoid arthritis patients treated with anakinra for up to 50 months". We are unable to draw any conclusions regarding malignancy due to the overall small number of participants in the studies.

\section{Comparative harms}

We did not locate any studies that directly compared the incidence of adverse events between anakinra and other biologics. We calculated a higher crude incidence of injection site reactions for anakinra (67.2\%, 95\% CI 38.7 to 95.7$)$ compared with adalimumab $(17.5 \%, 95 \%$ CI 7.1 to $27.9)$ and etanercept $(22.4 \%, 95 \%$ CI 8.5 to 36.3$)$. This is consistent with numbers reported in the respective package inserts. ${ }^{38-40}$

\section{Combination strategies}

\section{Anakinra combined with etanercept compared with etanercept alone}

One RCT compared anakinra $100 \mathrm{mg}$ /day combined with 2 different doses of the anti-TNF agent etanercept $(25 \mathrm{mg} /$ once a week or $25 \mathrm{mg} /$ twice a week) with etanercept alone ( $25 \mathrm{mg} /$ twice a week) in 242 patients with moderate rheumatoid arthritis. ${ }^{30}$ After 24 weeks of therapy $41 \%$ of patients in the etanercept groups had an ACR50 response, compared with $39 \%$ of those receiving once weekly etanercept and anakinra, and $31 \%$ in the groups who received the combination of twice weekly etanercept and daily anakinra (results not statistically significant). The odds ratio for an ACR50 response for the etanercept plus anakinra groups versus the etanercept alone group was 0.64 (95\% CI 0.37 to 1.09 ).

Furthermore, $15 \%$ of patients in the twice-weekly etanercept plus anakinra group experienced a serious adverse event, compared with $2.5 \%$ in the etanercept alone group and $5 \%$ in the once-weekly etanercept and anakinra group. Twenty-two percent of patients in the anakinra/etanercept once per week group and $20 \%$ of the patients randomized to anakinra and etanercept twice per week did not complete the study compared with $7 \%$ of patients receiving etanercept alone. Injection-site reactions were the common reason for adverse-event related withdrawal from the study. Injection site reactions occurred in $69 \%$ of patients receiving combination therapy compared with $40 \%$ of those receiving etanercept alone.

\section{Subgroups}

We did not locate any studies that provided results on the efficacy or safety of anakinra for subgroups.

\section{Discussion}

In this systematic review, we found 3 RCTs that confirmed the efficacy of anakinra compared with placebo for adult patients with RA. Our results are consistent with several other published systematic reviews of anakinra. ${ }^{20,41-43}$ In one RCT that used a combination of anakinra and etanercept the response rates were not better than etanercept alone, and the adverse events rates were significantly higher. There appears to be greater harm and no additional benefit in combining anakinra and the anti-TNF drugs.

No direct evidence comparing anakinra and other biologics exists, however our indirect comparision of anakinra and anti-TNF agents as a class revealed a non-significant RR of 0.67 (95\% CI 0.38 to 1.17 ) that favors the anti-TNF drugs adalimumab, etanacerpt and infliximab. The authors of a meta-analysis with indirect comparisons calculated that anakinra is inferior to adalimumab, etanercept and infliximab. ${ }^{20}$ This result was statistically significant. Our update, which includes several newer studies of the anti-TNF biologics, indicates a lesser degree of certainty. 
Table 4 Summary of studies assessing adverse events

\begin{tabular}{|c|c|c|c|c|}
\hline First author & $\begin{array}{l}\text { Study design } \\
\text { N Duration }\end{array}$ & $\begin{array}{l}\text { Population } \\
\text { comparison }\end{array}$ & Results & $\begin{array}{l}\text { Quality } \\
\text { rating }\end{array}$ \\
\hline Bresnihan et $\mathrm{a}^{27}$ & $\begin{array}{l}\text { RCT } \\
472 \\
24 \text { wks }\end{array}$ & $\begin{array}{l}>6 \text { months active } \\
\text { severe RA, NSAIDs, } \\
\text { steroids }<10 \mathrm{mg} / \text { day } \\
\text { allowed, no other } \\
\text { DMARDs Placebo }\end{array}$ & $\begin{array}{l}\text { More patients with ISRs in AKA groups compared with } \\
\text { placebo: } 30 \mathrm{mg} / \text { day } 50 \% \text {; } 70 \mathrm{mg} / \text { day } 73 \% \text {; } 150 \mathrm{mg} / \text { day } 81 \% \text {; } \\
\text { placebo } 25 \% \\
\text { Infections resulting in antibiotic use in I } 2 \% \text { placebo vs } \\
15 \%-17 \% \text { AKA; of the } 6 \text { patients hospitalized for infections } 4 \\
\text { were in the AKA } 150 \mathrm{mg} / \text { day group vs I each from placebo } \\
\text { and } 75 \mathrm{mg} / \text { day } \\
\text { Two patients in AKA group developed a malignancy, neu- } \\
\text { tropenia occurred in } 3 \text { AKA patients compared with no } \\
\text { placebo patients }\end{array}$ & Fair \\
\hline Nuki et al ${ }^{19}$ & $\begin{array}{l}\text { Uncontrolled } \\
\text { extension of } \\
\mathrm{RCT}^{27} \\
309 \\
76 \text { weeks }\end{array}$ & $\begin{array}{l}\text { Patients with RA } \\
\text { randomized to } \\
30 \mathrm{mg} / \text { day, } \\
75 \mathrm{mg} / \text { day or } \\
150 \mathrm{mg} / \text { day AKA }\end{array}$ & $\begin{array}{l}\text { The most common AE was ISR. } \\
\text { ISRs occurred in } 72 \% \text { of patients who received } 75 \mathrm{mg} / \text { day } \\
\text { and } 80 \% \text { of patients who received I } 50 \mathrm{mg} / \text { day over the } \\
76 \text { week study } \\
30 \% \text { AKA withdrew from study, I } 4 \% \text { withdrew due to AEs }\end{array}$ & Fair \\
\hline Cohen et $\mathrm{al}^{28}$ & $\begin{array}{l}\text { RCT } \\
419 \\
24 \text { weeks }\end{array}$ & $\begin{array}{l}\text { 6- to 8-year history } \\
\text { of moderate-severe } \\
\text { RA, stable dose MTX } \\
\text { (15-25 mg/week) placebo }\end{array}$ & $\begin{array}{l}\text { ISRs reported more frequently in AKA I mg/kg and } 2 \mathrm{mg} / \mathrm{kg} \\
\text { groups (64\% and 63\%) compared with placebo } 28 \% \\
\text { Five patients in the AKA groups experienced leukopenia } \\
\text { I3.6\% (I mg/kg/day) and } 15.3 \% \text { ( } 2 \mathrm{mg} / \mathrm{kg} / \text { day) withdrew due } \\
\text { to AEs }\end{array}$ & Fair \\
\hline $\begin{array}{l}\text { Fleischmann et } \mathrm{al}^{4} \\
\text { Schiff et } \mathrm{al}^{6} \\
\text { Tesser et } \mathrm{al}^{5} \\
\text { Fleischmann et } \mathrm{al}^{33}\end{array}$ & $\begin{array}{l}\text { RCT with } \\
\text { open-label } \\
\text { follow-up } 1399 \\
\text { RCT } 6 \text { months } \\
\text { Open-label } \\
3 \text { years }\end{array}$ & $\begin{array}{l}>3 \text { month active RA; } \\
\text { stable NSAIDs, steroids, } \\
\text { DMARDs dose placebo }\end{array}$ & $\begin{array}{l}\text { Rate of ISRs significantly higher in AKA group compared } \\
\text { with placebo ( } 72.6 \% \text { vs } 32.9 \%) \\
\text { At } 6 \text { months, there were more serious infections in AKA } \\
\text { group }(2.1 \%) \text { vs placebo }(0.4 \%) \text { not statistically significant; } \\
\text { after } 3 \text { years the exposure adjusted event rates were AKA } \\
5.4 / 100 \text { patient-years vs placebo } 1.6 / 100 \text { patient-years } \\
\text { The event rate for pneumonia occurred was } 1.28 \text { per } 100 \\
\text { patient-years } \\
\text { After } 3 \text { years of therapy, incidence rates for melanoma } \\
\text { and lymphoma were higher than expected for the general } \\
\text { population }\end{array}$ & Fair \\
\hline Cohen et $\mathrm{al}^{29}$ & $\begin{array}{l}\text { RCT } \\
50 \mathrm{I} \\
24 \text { weeks }\end{array}$ & $\begin{array}{l}>6 \text { months history of } \\
\text { active RA; stable MTX } \\
\text { regimen; mean disease } \\
\text { duration: } 10.5 \text { years. } \\
\text { placebo }\end{array}$ & $\begin{array}{l}65 \% \text { of patients in the AKA groups experienced ISR } \\
\text { compared with } 24 \% \text { in the placebo group }\end{array}$ & Fair \\
\hline Genovese et $\mathrm{a}^{30}$ & $\begin{array}{l}\text { RCT } \\
242 \\
24 \text { weeks }\end{array}$ & $\begin{array}{l}\text { >6-month history of RA; } \\
\text { stable dose MTX; approx } \\
50 \% \text { also using steroids } \\
\text { AKA combined with } \\
\text { ETA vs ETA alone }\end{array}$ & $\begin{array}{l}\text { More patients receiving AKA in addition to ETA experienced } \\
\text { AEs, including ISR and serious infections, compared with } \\
\text { ETA alone }\end{array}$ & Fair \\
\hline Langer et $\mathrm{al}^{36}$ & $\begin{array}{l}\text { Case series } \\
\text { efficacy }-166 \\
\text { safety }-454 \text { up } \\
\text { to } 6 \text { months }\end{array}$ & $\begin{array}{l}\text { Patients with RA receiving } \\
\text { AKA; population-based }\end{array}$ & $\begin{array}{l}\text { Rate of adverse events was similar to those reported } \\
\text { in efficacy trials } \\
42.2 \% \text { of patients experienced AEs: } 20.7 \% \text { had ISRs; } 4.2 \% \\
\text { serious AEs; } 5.1 \% \text { infectious episodes. }\end{array}$ & Fair \\
\hline Listing et $\mathrm{al}^{34}$ & $\begin{array}{l}\text { Prospective } \\
\text { cohort study } \\
1529 \\
\text { Up to } \\
12 \text { months }\end{array}$ & $\begin{array}{l}\text { Infections in patients } \\
\text { with RA treated with } \\
\text { AKA, ETA, INF, DMARDs } \\
\text { (German RABBIT cohort) }\end{array}$ & $\begin{array}{l}70 \text { patients received open-label AKA. Those that received a } \\
\text { biologic had more severe disease than the control patients } \\
\text { receiving a DMARD } \\
\text { Infections were observed in I } 3 \% \text { of AKA patients compared } \\
\text { to } 6 \% \text { of control patients } \\
\text { AEs occurred at a rate of } 17.5 / 100 \text { patient-years for AKA } \\
\text { Serious AEs occurred at } 3.2 / 100 \text { patient-years }\end{array}$ & Fair \\
\hline
\end{tabular}


Table 4 (Continued)

\begin{tabular}{|c|c|c|c|c|}
\hline First author & $\begin{array}{l}\text { Study design } \\
\text { N Duration }\end{array}$ & $\begin{array}{l}\text { Population } \\
\text { comparison }\end{array}$ & Results & $\begin{array}{l}\text { Quality } \\
\text { rating }\end{array}$ \\
\hline Zink et $\mathrm{al}^{35}$ & $\begin{array}{l}\text { Prospective } \\
\text { cohort } \\
\text { study } 1523 \\
12 \text { months }\end{array}$ & $\begin{array}{l}\text { Patients with RA treated } \\
\text { with AKA, ETA, INF } \\
\text { (German RABBIT cohort) }\end{array}$ & $\begin{array}{l}\text { Of the } 70 \text { patients receiving AKA, } 4 \text { I\% discontinued } \\
\text { treatment within I } 2 \text { months: } 16.3 \% \text { discontinued due to AEs; } \\
29.6 \% \text { discontinued due to lack of efficacy } \\
\text { In comparison, } 31.4 \% \text { of patients receiving ETA and } 34.6 \% \\
\text { of patients receiving INF discontinued therapy within } \\
\text { I } 2 \text { months }\end{array}$ & Fair \\
\hline
\end{tabular}

Abbreviations: ACR 20/50/70, American College of Rheumatology (numbers refer to percentage improvement); ADA, adalimumab; AE, adverse event; AKA, anakinra; ASHI, arthritis-specific health index; DAS28, disease activity score; DMARD, disease-modifying antirheumatic drug; ETA, etanercept; EULAR, European League Against Rheumatism; HAQ, Health Assessment Questionnaire; ISR, injections site reaction; MA, meta-analysis; MTX, methotrexate; RA, rheumatoid arthritis; RCT, randomized controlled trial; SF-36, Medical Outcomes Study Short Form 36 Health Survey; SJC, swollen joint count; TJC, tender joint count.

Patients receiving anakinra experienced more injection site reactions and serious infections than patients receiving placebo. The number of patients in the included trails was too small to reach any conclusions regarding malignancies.

Our review has limitations. We did not locate any direct comparisons of anakinra compared with other biologics. Like other authors, we have relied on indirect comparisons to report the comparative efficacy of anakinra with other biologics. Although evidence suggests that adjusted indirect comparisons agree with head-to-head trials if component studies are similar and treatment effects are expected to be consistent in patients included in different trials, results have to be interpreted cautiously. Many of the underlying assumptions of indirect comparisons are not verifiable and confidence intervals are often wide leading to indeterminate results. Nevertheless, in the absence of direct evidence indirect comparisons can provide valuable information about the comparative efficacy of drugs.

Secondly, publication bias is an issue for all systematic reviews. Selective availability of studies with positive results can seriously bias conclusions of systematic reviews, particularly when the focus is on placebo controlled trials which are generally conducted for regulatory approval by the manufacturer of a specific drug. All three placebo-controlled trials included in this review were funded by Amgen, Thousand Oaks, CA, US, the makers of anakinra.

Finally, all of the studies we included for efficacy were conducted in patients with moderate to severe rheumatoid arthritis with an average disease duration of 6 to 10 years who also took anti-inflammatory drugs, corticosteroids and in 3 trials also methotrexate. The applicability of their results to the average patient with rheumatoid arthritis might be limited.

\section{Conclusion}

Anakinra is certainly effective for treating moderate to severe RA that is resistant to traditional DMARDs in comparison with placebo. Indirect comparisons with adalimumab, etanercept and infliximab, however, showed a trend towards greater efficacy for the anti-TNF drugs. Anakinra also seems to be associated with comparably high rates of injection site reactions. The frequency of administration (daily) might also disadvantage anakinra in comparison with these agents, although the subcutaneous route of administration may be preferable to intravenous. Our results and these factors should be taken into account when considering biologic therapy for patients with RA.

\section{Acknowledgments}

We wish to thank Laura Morgen from the University of North Carolina at Chapel Hill and our colleagues from the Danube University Krems Andrea Chapman and Irene Wild for help with literature searches and for administrative support.

\section{Funding}

The original comparative effectiveness report was funded through a contract from the University of North Carolina Evidence-based Practice Center with the Oregon Health and Science University under the Drug Effectiveness Review Project. We have received no funding for this update.

\section{Disclosures}

Richard Hansen has received research support from NIH, AHRQ, and Takeda Pharmaceuticals. All the other authors declare that they have no conflicts of interest.

\section{References}

1. Saketkoo LA, Espinoza LR. Impact of biologic agents on infectious diseases. Infect Dis Clin North Am. 2006;20(4):931-961, viii.

2. Burmester GR, Mariette X, Montecucco C, et al. Adalimumab alone and in combination with disease-modifying antirheumatic drugs for the treatment of rheumatoid arthritis in clinical practice: the Research in Active Rheumatoid Arthritis (ReAct) trial. Ann Rheum Dis. 2007;66(6):732-739. 
3. Colombel JF, Loftus EV Jr, Tremaine WJ, et al. The safety profile of infliximab in patients with Crohn's disease: the Mayo clinic experience in 500 patients. Gastroenterology. 2004;126(1):19-31.

4. Fleischmann RM, Schechtman J, Bennett R, et al. Anakinra, a recombinant human interleukin-1 receptor antagonist (r-metHuIL-1ra), in patients with rheumatoid arthritis: A large, international, multicenter, placebo-controlled trial. Arthritis Rheum. 2003;48(4):927-934.

5. Tesser J, Fleischmann R, Dore R, et al. Concomitant medication use in a large, international, multicenter, placebo controlled trial of anakinra, a recombinant interleukin 1 receptor antagonist, in patients with rheumatoid arthritis. J Rheumatol. 2004;31(4):649-654.

6. Schiff MH, DiVittorio G, Tesser J, et al. The safety of anakinra in highrisk patients with active rheumatoid arthritis: six-month observations of patients with comorbid conditions. Arthritis Rheum. 2004;50(6): $1752-1760$.

7. Schaible TF, Long term safety of infliximab. Can J Gastroenterol. 2000;14 Suppl C:29C-32C.

8. Ljung T, Karlen P, Schmidt D, et al. Infliximab in inflammatory bowel disease: clinical outcome in a population based cohort from Stockholm County. Gut. 2004;53(6):849-853.

9. Takeuchi T, Tatsuki Y, Nogami Y, et al. Postmarketing surveillance of the safety profile of infliximab in 5000 Japanese patients with rheumatoid arthritis. Ann Rheum Dis. 2008;67(2):189-194.

10. Fleurence R, Spackman E. Cost-effectiveness of biologic agents for treatment of autoimmune disorders: Structured review of the literature, in Journal of Rheumatology. 2006:2124.

11. Gartlehner G, Thieda P, Morgan LC, et al. Drug Effectiveness Review Project: Targeted Immune Modulators. Portland: Oregon Health and Science University; In press. 2009.

12. Grabowski H, Cockburn I, Long G. The market for follow-on biologics: how will it evolve? Health Aff (Millwood). 2006;25(5):1291-1301.

13. Roos JC, Ostor AJ. Tumor necrosis factor inhibitors for rheumatoid arthritis. N Engl J Med. 2006;355(19):2046-2047; author reply 2048.

14. Krueger G, Callis K. Potential of tumor necrosis factor inhibitors in psoriasis and psoriatic arthritis. Arch Dermatol (USA). 2004;140:218.

15. NesbittA, Fossati G, Bergin M, et al. Mechanism of action of certolizumab pegol (CDP870): in vitro comparison with other anti-tumor necrosis factor alpha agents. Inflamm Bowel Dis. 2007;13(11):1323-1332.

16. Chitale S, Moots R. Abatacept: the first T lymphocyte co-stimulation modulator, for the treatment of rheumatoid arthritis. Expert Opin Biol Ther. 2008;8(1):115-122.

17. Ko HH, Bressler B. Natalizumab: pharmacology, clinical efficacy and safety in the treatment of patients with Crohn's disease. Expert Rev Gastroenterol Hepatol. 2007;1(1):29-39.

18. Schuna AA. Rituximab for the treatment of rheumatoid arthritis. Pharmacotherapy. 2007;27(12):1702-1710.

19. Nuki G, Bresnihan B, Bear MB, McCabe D. Long-term safety and maintenance of clinical improvement following treatment with anakinra (recombinant human interleukin-1 receptor antagonist) in patients with rheumatoid arthritis: extension phase of a randomized, double-blind, placebo-controlled trial. Arthritis Rheum. 2002;46(11):2838-2846.

20. Nixon R, Bansback N, Brennan A. The efficacy of inhibiting tumour necrosis factor alpha and interleukin 1 in patients with rheumatoid arthritis: a meta-analysis and adjusted indirect comparisons. Rheumatology. 2007;46(7):1140-1147.

21. Harris RP, Helfand M, Woolf SH, et al. Current methods of the US Preventive Services Task Force: a review of the process. Am J Prev Med. 2001;20(3 Suppl):21-35.

22. Deeks JJ, Dinnes J, D'Amico R, et al. Evaluating non-randomised intervention studies. Health Technol Assess. 2003;7(27):iii-x, $1-173$.

23. Gartlehner G, Hansen RA, Nissman D, Lohr KN, Carey V. A simple and valid tool distinguished efficacy from effectiveness studies. $J$ Clin Epidemiol. 2006;59(10):1040-1048.

24. Bucher HC, Guyatt GH, Griffith LE, Walter SD. The results of direct and indirect treatment comparisons in meta-analysis of randomized controlled trials. J Clin Epidemiol. 1997;50(6):683-691.
25. Song F, Altman DG, Glenny AM, Deeks JJ. Validity of indirect comparison for estimating efficacy of competing interventions: empirical evidence from published meta-analyses. Bmj. 2003;326(7387):472.

26. Sauriol L, Laporta M, Edwardes MD, et al. Meta-analysis comparing newer antipsychotic drugs for the treatment of schizophrenia: evaluating the indirect approach. Clin Ther. 2001;23(6):p. 942-956.

27. Bresnihan B, Alvaro-Gracia JM, Cobby M, et al. Treatment of rheumatoid arthritis with recombinant human interleukin-1 receptor antagonist. Arthritis Rheum. 1998;41(12):2196-2204.

28. Cohen S, Hurd E, Cush J, et al. Treatment of rheumatoid arthritis with anakinra, a recombinant human interleukin-1 receptor antagonist, in combination with methotrexate: results of a twenty-four-week, multicenter, randomized, double-blind, placebo-controlled trial. Arthritis Rheum. 2002;46(3):614-624.

29. Cohen SB, Moreland LW, Cush JJ, et al. A multicentre, double blind, randomised, placebo controlled trial of anakinra (Kineret), a recombinant interleukin 1 receptor antagonist, in patients with rheumatoid arthritis treated with background methotrexate. Ann Rheum Dis. 2004;63(9):1062-1068.

30. Genovese MC, Cohen S, Moreland L, et al. Combination therapy with etanercept and anakinra in the treatment of patients with rheumatoid arthritis who have been treated unsuccessfully with methotrexate. Arthritis Rheum. 2004;50(5):1412-1419.

31. US Food and Drug Administration. Centre for Drug Evaluation and Research. Drugs@FDA: Kineret 2009 [cited 2009 10th August]; URL: http://www.accessdata.fda.gov/Scripts/cder/DrugsatFDA/index. $\mathrm{cfm}$ ? fuseaction=Search.DrugDetails.

32. Cohen SB, Moreland L, Cush JJ, et al. Anakinra (recombinant interleukin-1 receptor antagonist): a large, placebo controlled efficacy trial of anakinra in patients with erosive rheumatoid arthritis disease. Arthritis Rheum. 2001;44:LB1.

33. Fleischmann RM, Tesser J, Schiff MH, et al. Safety of extended treatment with anakinra in patients with rheumatoid arthritis. Ann Rheum Dis. 2006;65(8):1006-1012.

34. Listing J, Strangfeld A, Kary S, et al. Infections in patients with rheumatoid arthritis treated with biologic agents. Arthritis Rheum. 2005;52(11):3403-3412.

35. Zink A, Listing J, Kary S, et al. Treatment continuation in patients receiving biological agents or conventional DMARD therapy. Ann Rheum Dis. 2005;64(9):1274-1279.

36. Langer HE, Missler-Karger B. Kineret: efficacy and safety in daily clinical practice: an interim analysis of the Kineret response assessment initiative (kreative) protocol. Int J Clin Pharmacol Res. 2003;23(4):119-128.

37. Salliot C, Dougados M, Gossec L. Risk of serious infections during rituximab, abatacept and anakinra treatments for rheumatoid arthritis: meta-analyses of randomised placebo-controlled trials. Ann Rheum Dis. 2009;68(1):25-32.

38. Humira ${ }^{\circledR}$ (adalimumab) FDA label information. URL: http://www. accessdata.fda.gov/drugsatfda_docs/label/2008/125057s114lbl.pdf. 2008 .

39. Kineret $^{\mathbb{}}$ (anakinra) FDA label information. URL http://www.accessdata. fda.gov/drugsatfda_docs/label/2004/103950s5039lbl.pdf. 2004.

40. FDA. Enbrel ${ }^{\circledR}$ (etanercept) FDA label information. URL http://www. accessdata.fda.gov/drugsatfda_docs/label/2008/103795s5359lbl.pdf. 2009 [cited 2009; Available from: http://www.accessdata.fda.gov/ drugsatfda_docs/label/2008/103795s5359lbl.pdf.

41. Clark W, Jobanputra P, Barton P, Burls A. The clinical and cost-effectiveness of anakinra for the treatment of rheumatoid arthritis in adults: a systematic review and economic analysis. Health Technol Assess. 2004;8(18):iii-iv, ix-x, 1-105.

42. Mertens M, Singh JA. Anakinra for rheumatoid arthritis. Cochrane Database Syst Rev. 2009(1):CD005121.

43. Wailoo A, Brennan A, Bansback N, et al. Modeling the cost effectiveness of etanercept, adalimumab and anakinra compared to infliximab in the treatment of patients with rheumatoid arthritis in the Medicare program. AHRQ Technology Assessment Program. 2006. 


\section{Appendix I}

Appendix I Anti-TNF biologic studies included for indirect comparisons with anakinra

\begin{tabular}{|c|c|c|c|c|c|c|}
\hline Author & $\begin{array}{l}\text { Study } \\
\text { design }\end{array}$ & $\mathbf{N}$ & Duration & Comparisons & $\begin{array}{l}\text { Primary } \\
\text { outcome }\end{array}$ & Population \\
\hline Furst et al' & RCT & 636 & 24 weeks & $\begin{array}{l}\text { ADA + Standard } \\
\text { RA therapy/Placebo + } \\
\text { Standard RA therapy }\end{array}$ & Safety & $\begin{array}{l}\text { Active RA for at least } 3 \text { months; } \\
\text { DMARD naive/or on stable regimen; } \\
\text { mean disease duration: } 10.5 \text { years. }\end{array}$ \\
\hline $\begin{array}{l}\text { Keystone } \\
\text { et } \mathrm{al}^{2}\end{array}$ & RCT & 619 & 52 weeks & ADA + MTX/Placebo + MTX & $\begin{array}{l}\text { Sharp, } \\
\text { ACR 20, } \\
\text { HAQ }\end{array}$ & $\begin{array}{l}\text { Active RA; on stable MTX regimen; } \\
\text { mean disease duration: I I years. }\end{array}$ \\
\hline Kim et $\mathrm{al}^{3}$ & $\mathrm{RCT}$ & 128 & 24 weeks & $A D A+M T X / M T X$ & ACR 20 & $\begin{array}{l}\text { Active RA; had failed at least } \\
\text { I DMARD treatment; mean disease } \\
\text { duration: } 6.9 \text { years. }\end{array}$ \\
\hline $\begin{array}{l}\text { Miyasaka } \\
\text { et } \mathrm{al}^{4}\end{array}$ & $\mathrm{RCT}$ & 352 & 24 weeks & ADA/Placebo & ACR 20 & $\begin{array}{l}\text { Active RA; had failed at least } \\
\text { I DMARD treatment; mean disease } \\
\text { duration: } 9.5 \text { years. }\end{array}$ \\
\hline $\begin{array}{l}\text { Van de Putte } \\
\text { et al }\end{array}$ & RCT & 284 & 12 weeks & ADA/Placebo & ACR 20 & $\begin{array}{l}\text { Active RA; had failed at least } \\
\text { I DMARD treatment; mean disease } \\
\text { duration: } 10 \text { years. }\end{array}$ \\
\hline $\begin{array}{l}\text { Van de Putte } \\
\text { et al }\end{array}$ & RCT & 544 & 26 weeks & ADA/Placebo & ACR20 & $\begin{array}{l}\text { Active RA; had failed at least } \\
\text { I DMARD treatment; mean disease } \\
\text { duration: I I years. }\end{array}$ \\
\hline $\begin{array}{l}\text { Weinblatt } \\
\text { et } \mathrm{al}^{7}\end{array}$ & RCT & 271 & 24 weeks & ADA + MTX/MTX + Placebo & $\begin{array}{l}\text { ACR20, } \\
\text { HAQ }\end{array}$ & $\begin{array}{l}\text { Active RA; stable MTX regimen; had } \\
\text { failed at least I other DMARD; mean } \\
\text { disease duration: I } 2 \text { years. }\end{array}$ \\
\hline $\begin{array}{l}\text { Klareskog } \\
\text { et al }\end{array}$ & RCT & 682 & 52 weeks & ETA/MTX/MTX + ETA & Sharp & $\begin{array}{l}>6 \text { months active RA;ACR functional } \\
\text { class I-III; unsatisfactory response to at } \\
\text { least I DMARD other than MTX; mean } \\
\text { disease duration: } 6.5 \text { years. }\end{array}$ \\
\hline Lan et al ${ }^{9}$ & $\mathrm{RCT}$ & 58 & 12 weeks & ETA + MTX/Placebo + MTX & $\begin{array}{l}\text { Number } \\
\text { of swollen/ } \\
\text { tender joints }\end{array}$ & $\begin{array}{l}\text { Active RA > I year; stable MTX for } \\
4 \text { weeks; mean disease duration: NR }\end{array}$ \\
\hline $\begin{array}{l}\text { Moreland } \\
\text { et } \mathrm{al}^{10}\end{array}$ & RCT & 180 & 12 weeks & ETA/Placebo & $\begin{array}{l}\text { Number } \\
\text { of swollen/ } \\
\text { tender joints }\end{array}$ & $\begin{array}{l}\text { Active RA; failed I to } 4 \text { DMARD } \\
\text { treatments; mean disease duration: NR }\end{array}$ \\
\hline $\begin{array}{l}\text { Moreland } \\
\text { et al }{ }^{11,12}\end{array}$ & RCT & 234 & 12 weeks & ETA/Placebo & ACR 20/50 & $\begin{array}{l}\text { Active RA; failed I to } 4 \text { DMARD } \\
\text { treatments other than MTX; mean } \\
\text { disease duration: I } 2 \text { years. }\end{array}$ \\
\hline $\begin{array}{l}\text { Weinblatt } \\
\text { et } \mathrm{al}^{13}\end{array}$ & RCT & 89 & 24 weeks & ETA + MTX/Placebo + MTX & ACR 20 & $\begin{array}{l}\text { Active RA; }>6 \text { months MTX, } \\
\text { stable }>\text { I month; mean disease } \\
\text { duration: I } 3 \text { years }\end{array}$ \\
\hline Abe et $\mathrm{al}^{14}$ & RCT & 147 & I4 weeks & INF + MTX/Placebo + MTX & ACR 20 & $\begin{array}{l}>6 \text { months history of active RA; mean } \\
\text { disease duration } 7.9 \text { years. }\end{array}$ \\
\hline $\begin{array}{l}\text { Kavanaugh } \\
\text { et } \mathrm{al}^{15}\end{array}$ & $\mathrm{RCT}$ & 28 & 12 weeks & INF + MTX/Placebo + MTX & ACR 20 & $\begin{array}{l}\text { RA }<15 \text { years; } M T X>3 \text { months; } \\
\text { mean disease duration } 4.9 \text { to } 7.5 \text { years. }\end{array}$ \\
\hline Maini et a $\left.\right|^{16}$ & RCT & 43 & 26 weeks & INF + MTX/Placebo + MTX & Paulus 20 & $\begin{array}{l}\text { MTX }>6 \text { months; mean disease } \\
\text { duration } 7.6 \text { to II } 4.3 \text { years. }\end{array}$ \\
\hline Maini et al ${ }^{17}$ & RCT & 428 & 30 weeks & INF + MTX/Placebo + MTX & ACR 20 & $\begin{array}{l}\text { MTX stable }>4 \text { weeks; mean disease } \\
\text { duration } 7.2 \text { to } 9.0 \text { years. }\end{array}$ \\
\hline $\begin{array}{l}\text { Westhovens } \\
\text { et al }{ }^{18}\end{array}$ & RCT & 1084 & 22 weeks & INF + MTX/Placebo + MTX & ACR 20 & $\begin{array}{l}\text { Active RA despite MTX treatment; } \\
\text { median disease duration: } 15 \text { years. }\end{array}$ \\
\hline Zhang et al ${ }^{19}$ & RCT & 173 & 18 weeks & INF + MTX/MTX & $\begin{array}{l}\text { ACR } \\
\text { 20/50/70 }\end{array}$ & $\begin{array}{l}\text { Adult outpatients with active RA } \\
\text { and insufficient response to standard } \\
\text { antirheumatic therapy. }\end{array}$ \\
\hline
\end{tabular}

Abbreviations: ACR20/50/70, American College of Rheumatology (numbers refer to percentage improvement); DMARD, disease-modifying antirheumatic drug; ETA, etanercept; HAQ, Health Assessment Questionnaire; MTX, methotrexate; N, number; NR, not reported; RA, rheumatoid arthritis; RCT, randomized controlled trial. 


\section{Appendix I: References}

1. Furst DE, et al. Adalimumab, a fully human anti tumor necrosis factor-alpha monoclonal antibody, and concomitant standard antirheumatic therapy for the treatment of rheumatoid arthritis: results of STAR (Safety Trial of Adalimumab in Rheumatoid Arthritis). J Rheumatol. 2003;30(12):2563-25671.

2. Keystone EC, et al. Radiographic, clinical, and functional outcomes of treatment with adalimumab (a human anti-tumor necrosis factor monoclonal antibody) in patients with active rheumatoid arthritis receiving concomitant methotrexate therapy: a randomized, placebo-controlled, 52-week trial. Arthritis Rheum. 2004;50(5):1400-1411.

3. Kim HY, et al. A randomized, double-blind, placebo-controlled, phase III study of the human anti-tumor necrosis factor antibody adalimumab administered as subcutaneous injections in Korean rheumatoid arthritis patients treated with methotrexate. APLAR Journal of Rheumatology. 2007;10(1):9-16.

4. Miyasaka N. Clinical investigation in highly disease-affected rheumatoid arthritis patients in Japan with adalimumab applying standard and general evaluation: The CHANGE study. Mod Rheumatol, 2008;18(3):252-262.

5. van de Putte LB, et al. Efficacy and safety of the fully human antitumour necrosis factor alpha monoclonal antibody adalimumab (D2E7) in DMARD refractory patients with rheumatoid arthritis: a 12 week, phase II study. Ann Rheum Dis. 2003;62(12):1168-1177.

6. van de Putte LB, et al. Efficacy and safety of adalimumab as monotherapy in patients with rheumatoid arthritis for whom previous disease modifying antirheumatic drug treatment has failed. Ann Rheum Dis. 2004;63(5):508-516.

7. Weinblatt ME, et al. Adalimumab, a fully human anti-tumor necrosis factor alpha monoclonal antibody, for the treatment of rheumatoid arthritis in patients taking concomitant methotrexate: the ARMADA trial. Arthritis Rheum. 2003;48(1):35-45.

8. Klareskog L, et al. Therapeutic effect of the combination of etanercept and methotrexate compared with each treatment alone in patients with rheumatoid arthritis: double-blind randomised controlled trial. Lancet. 2004;363(9410):675-681.
9. Lan JL, et al. A comparative study of etanercept plus methotrexate and methotrexate alone in Taiwanese patients with active rheumatoid arthritis: a 12-week, double-blind, randomized, placebo-controlled study. J Formos Med Assoc. 2004;103(8):618-623.

10. Moreland LW, et al. Treatment of rheumatoid arthritis with a recombinant human tumor necrosis factor receptor (p75)-Fc fusion protein. N Engl J Med. 1997;337(3):141-147.

11. Moreland LW, et al. Etanercept therapy in rheumatoid arthritis. A randomized, controlled trial. Ann Intern Med. 1999;130(6):478-486.

12. Mathias SD, et al. Health-related quality of life and functional status of patients with rheumatoid arthritis randomly assigned to receive etanercept or placebo. Clin Ther. 2000;22(1):128-139.

13. Weinblatt ME, et al. A trial of etanercept, a recombinant tumor necrosis factor receptor: Fc fusion protein, in patients with rheumatoid arthritis receiving methotrexate. $N$ Engl J Med. 1999;340(4):253-259.

14. Abe T, et al. A multicenter, double-blind, randomized, placebo controlled trial of infliximab combined with low dose methotrexate in Japanese patients with rheumatoid arthritis. J Rheumatol. 2006;33(1):37-44.

15. Kavanaugh A, et al. Chimeric anti-tumor necrosis factor-alpha monoclonal antibody treatment of patients with rheumatoid arthritis receiving methotrexate therapy. J Rheumatol. 2000;27(4):841-850.

16. Maini RN, et al; Therapeutic efficacy of multiple intravenous infusions of anti-tumor necrosis factor alpha monoclonal antibody combined with low-dose weekly methotrexate in rheumatoid arthritis. Arthritis Rheum. 1998;41(9):1552-1563.

17. Maini R, et al. Infliximab (chimeric anti-tumour necrosis factor alpha monoclonal antibody) versus placebo in rheumatoid arthritis patients receiving concomitant methotrexate: a randomised phase III trial. ATTRACT Study Group. Lancet. 1999;354(9194):1932-1939.

18. Westhovens R, et al. The safety of infliximab, combined with background treatments, among patients with rheumatoid arthritis and various comorbidities: a large, randomized, placebo-controlled trial. Arthritis Rheum. 2006;54(4):1075-1086.

19. Zhang FC, et al. Infliximab versus placebo in rheumatoid arthritis patients receiving concomitant methotrexate: A preliminary study from China. APLAR Journal of Rheumatology. 2006;9(2):127-130.
Biologics: Targets \& Therapy

\section{Publish your work in this journal}

Biologics: Targets \& Therapy is an international, peer-reviewed journal focusing on the patho-physiological rationale for and clinical application of Biologic agents in the management of autoimmune diseases, cancers or other pathologies where a molecular target can be identified. This journal is indexed on PubMed Central, CAS,

\section{Dovepress}

EMBase, Scopus and the Elsevier Bibliographic databases. The manuscript management system is completely online and includes a very quick and fair peer-review system, which is all easy to use. Visit http://www.dovepress.com/testimonials.php to read real quotes from published authors. 